\title{
MODEL PEMETAAN RISIKO KEKERINGAN DI KABUPATEN BIMA, NUSA TENGGARA BARAT
}

\section{MAPPING MODEL OF DROUGHT RISK IN BIMA REGENCY, WEST NUSA TENGGARA}

\author{
Nuraimmatul Faizah', Imam Buchori² \\ ${ }^{1}$ Magister Perencanaan Wilayah dan Kota, Universitas Diponegoro; n.faizah24@yahoo.com \\ 2Departemen Perencanaan Wilayah dan Kota, Universitas Diponegoro; i.buchori@gmail.com
}

\section{Info Artikel:}

Artikel Masuk: 26 Juli 2018

Artikel diterima: 17 September 2018

Tersedia Online: 31 Mei 2019

\begin{abstract}
ABSTRAK
Kekeringan di Kabupaten Bima merupakan kejadian yang selalu berulang tiap tahunnya dan penanganannya masih bersifat jangka pendek. Oleh karena itu, perlu dilakukan upaya pemantauan dan menganalisis faktor-faktor risiko kekeringan, agar dapat dikembangkan model pemetaan risiko kekeringan yang dapat digunakan untuk perencanaan mitigasi bencana kekeringan. Penelitian ini bertujuan untuk mengembangkan model pemetaan risiko kekeringan dengan Sistem Informasi Geografis untuk mengetahui sebaran tingkat risiko kekeringan di Kabupaten Bima berdasarkan variabel terkait. Model risiko kekeringan yang digunakan sebagai dasar penelitian yaitu interseksi antara kerawanan (Hazard) dan kerentanan (Vulnerability), yang merupakan model dasar dalam kajian risiko bencana. Penelitian ini menggunakan pendekatan keruangan/spasial dengan metode kuantitatif yang menggunakan indikator statistik untuk mengukur dan membandingkan berbagai variabel. Pengumpulan data dilakukan dengan survei instansional dan literatur. Data yang digunakan adalah data sekunder. Teknik analisis data yang digunakan adalah analisis skoring, pembobotan, dan overlay peta. Hasil model pemetaan risiko kekeringan di Kabupaten Bima diklasifikasikan menjadi 5 kelas, dengan didominasi oleh kelas Sedang. Luas wilayah dengan kelas dari yang tertinggi ke yang terendah yaitu Sedang $\pm 223.232,40$ ha, Agak rendah $\pm 136.414,29$ ha, Agak tinggi $\pm 47.971,49$ ha, Rendah $\pm 10.962,28$ ha dan Tinggi $\pm 1.776,53$ ha. Kemudian dilakukan validasi model melalui survey lapangan, dengan hasil kevalidan 83,61\%. Hasil tersebut menunjukkan bahwa pemodelan cukup baik dalam menganalisis risiko kekeringan secara spasial. Untuk pengembangan kedepannya perlu memperhatikan model risiko yang digunakan, penggunaan data, unit analisis tiap parameter, dan validasi yang akan dilakukan.

Kata Kunci : Risiko Kekeringan, SIG, Pemetaan, Kabupaten Bima

\section{ABSTRACT}

Drought in Bima regency is an annual phenomenon that always happens every year and its handling is still short-term. Therefore, there needs to be a monitoring and analysis of the drought risk factors so the drought risk mapping can be conducted to plan the drought mitigation. This research aims to develop the drought risk mapping model with Geographic Information System to find out the drought risk level in Bima regency based on the relevant variables. The drought risk model used as the basic of the research is the intersection between hazard and vulnerability, which are the basic models in disaster risk study. This research uses spatial approach with quantitative method which uses statistic indicator to measure and compare several variables. The data was collected by using institutional and literature survey. The data used was secondary data. The data analysis technique used was scoring analysis, weighting, and map overlay. The result of drought risk mapping model in Bima regency was classified into 5 classes, dominated by the Middle Class. The width of the classes consequently from the highest to the lowest are: Middle $\pm 223.232,40$ ha, Middle Lower $\pm 136.414,29$ ha, Middle High $\pm 47.971,49$ ha, Low $\pm 10.962,28$ ha dan High $\pm 1.776,53$ ha. Then the model validation was conducted through field survey, with the validity result at $83,61 \%$. The result shows that the modeling was good enough in analyzing the drought risk spatially. For further development, it is recommended to notice the used risk model, data using, analysis unit for each parameter, and the validation that will be used.
\end{abstract}

Keyword: Drought risk, GIS, Mapping, Bima Regency 
Faizah, Buchori/ Jurnal Pembangunan Wilayah dan Kota, Vol.15, No.2, 2019, 138-150

Doi: https://doi.org/10.14710/pwk.v15i2.19621

\section{PENDAHULUAN}

Salah satu bencana alam yang masih menjadi permasalahan serius di Indonesia adalah bencana kekeringan. Menurut Bakornas Penanggulangan Bencana (2007), dari data historis, kekeringan di Indonesia sangat berkaitan erat dengan fenomena ENSO (El-Nino Southern Oscillation). Pengamatan dari tahun 1844, dari 43 kejadian kekeringan di Indonesia, hanya enam kejadian yang tidak berkaitan dengan kejadian El-Nino. Pengaruh El-Nino yang kuat ini dapat menyebabkan masa musim kemarau lebih lama daripada musim penghujan dan dapat menimbulkan bencana kekeringan yang lebih lama.

Beberapa peneliti menyebutkan bahwa kekeringan adalah salah satu bahaya alam yang paling rumit dan berulang yang memiliki dampak berbeda pada wilayah ekologi, ekonomi, sosial, pertanian, budaya dan politik (Kastopoulou et al., 2017; Surendran et al., 2017 dalam Mathbout et al., 2017) yang umumnya ditandai dengan frekuensi, tingkat keparahan dan durasi yang bervariasi (Loon, 2015). Tiga tanda atau dimensi tersebut juga bisa berarti tingkat keparahan (besaran atau intensitas), durasi dan luas areal (Mohammed \& Scholz, 2017) ataupun durasi, tingkat keparahannya, dan daerah yang terkena dampak (Kim et al., 2015). Lebih jauh, menurut Fontaine dan Steinemann (2009), kekeringan adalah fenomena berulang yang terus-menerus yang merupakan salah satu bencana alam yang paling mahal di dunia. Karena selanjutnya kekeringan diperkirakan akan semakin sering dan parah, dengan meningkatnya permintaan air karena pertumbuhan penduduk, persediaan air yang terbatas dan tidak pasti karena perubahan iklim dan variabilitas.

Kabupaten Bima merupakan salah satu kabupaten yang sering mengalami kekeringan. Menurut beberapa artikel, kekeringan di Kabupaten Bima diakibatkan karena dampak dari El-Nino sehingga terjadi kemarau panjang dan berkurangnya cadangan air bersih. Selain itu, kekeringan di Kabupaten Bima merupakan pengulangan setiap tahun pada saat peralihan musim hujan ke musim kemarau (pancaroba) dan hampir merata terjadi di wilayah Kabupaten Bima. Untuk mengatasi hal-hal tersebut, Pemerintah Daerah melakukan pendataan secara manual untuk mengidentifikasi wilayah yang terkena bencana kekeringan, lalu kemudian melakukan dropping atau mendistribusikan air bersih ke wilayah yang melaporkan terjadinya kekeringan hingga krisis air bersih.

Kekeringan dibedakan ke dalam tiga kategori, yaitu meteorologis, pertanian, dan hidrologis (Diaz et al., 2016; Hayes et al., 2011). Namun, pada umumnya para peneliti sebelumnya mengklasifikasikan kekeringan berdasarkan sifat defisit air (Wilhite dan Glantz, 1985) atau berdasarkan karakteristik dan dampak yang ditimbulkan (Reed, 1995) ke dalam empat jenis kekeringan, yaitu Kekeringan Meteorologis, Hidrologis, Pertanian, dan Sosial-Ekonomi.

Pada dasarnya, setiap bencana yang terjadi tidak akan sama antara wilayah yang satu dengan lainnya. Untuk itu, perlu adanya kajian risiko bencana untuk mengetahui potensi kerugian dan dampak yang akan terjadi serta upaya mitigasinya, termasuk risiko kekeringan di Kabupaten Bima. Risiko kekeringan di Kabupaten Bima biasanya berupa berkurangnya pasokan air untuk menunjang kehidupan sehari-hari, gagal panen, dan rusaknya lingkungan bahkan konflik sosial. BNPB (2010) telah memetakan indeks risiko kekeringan di Provinsi Nusa Tenggara Barat dengan skala 1:1.300.000, di mana Kabupaten Bima berada dalam kelas rendah. Namun, pemetaan tersebut memiliki cakupan besar dan belum dapat dipakai untuk penanggulangannya di daerah yang detail. Selain itu, mengingat kekeringan merupakan kejadian yang dapat berulang dan awal-akhir kekeringan sulit ditentukan, maka perlu dilakukan upaya pemantauan dan mengidentifikasi faktor-faktor risiko kekeringan, agar dapat dikembangkan model risiko kekeringan. Di samping itu, perlu adanya peta kerawanan kekeringan, kerentanan kekeringan serta risiko kekeringan yang dapat digunakan untuk perencanaan mitigasi bencana kekeringan.

Tujuan utama dari penelitian ini adalah mengembangkan model pemetaan risiko kekeringan dengan Sistem Informasi Geografis untuk mengetahui sebaran tingkat risiko kekeringan di Kabupaten Bima berdasarkan bahaya/kerawanan kekeringan dan kerentanan wilayah terhadap kekeringan. Dengan demikian, pada akhir penelitian ini dapat dihasilkan suatu arahan dan rekomendasi sebagai masukan untuk penyelenggaraan penanggulangan bencana kekeringan di Kabupaten Bima. 
Hingga saat ini, telah banyak berkembang model risiko bencana seiring dengan berkembangnya penelitian terkait risiko bencana. Misalnya dengan menggabungkan bahaya/kerawanan dengan kerentanan (Maskrey, 1989; Knutson et al., 1998; Wisner et al., 2003; Wu \& Wilhite, 2004; Shahid \& Behrawan, 2008; Verdon-Kidd \& Kiem, 2010; Lin et al., 2011; Kim et al., 2015; Valverde-Arias et al., 2018), atau ada juga yang menggabungkan antara probabilitas dengan kerugian (Smith, 1996 dalam Jia et al., 2016). Namun ada juga yang berpendapat bahwa risiko bencana berinteraksi dengan faktor kerawanan, keterpaparan dan kerentanan (Okada et al., 2004; Yan, 2010; Jia et al., 2016; Carra o et al., 2016). Dan ada pula yang menggunakan formula kerawanan dikali kerentanan lalu dibagi dengan kapasitas (Perka BNPB No.4, 2008; Prabowo, 2016).

Penelitian ini memberikan manfaat bagi keilmuan, peneliti sendiri, pemerintah dan masyarakat. Bagi keilmuan, dapat memberikan tambahan informasi mengenai deteksi dan pendekatan dalam pemecahan masalah bencana kekeringan dan bermanfaat untuk penilaian kerentanan kawasan terhadap kekeringan dari faktor sosial, ekonomi, dan lingkungan, sehingga didapatkan penilaian terhadap risiko kekeringan di lokasi penelitian. Bagi peneliti, dapat menambah dan memperkaya wawasan keilmuan, terutama penerapan teknologi dan pendekatan terhadap mitigasi bencana kekeringan. Bagi pemerintah, dapat mengetahui tingkat risiko kekeringan yang ada di Kabupaten Bima sekaligus menjadi suatu pedoman yang secara praktis dan masukan dalam menyusun suatu kebijakan terkait dengan kegiatan mitigasi bencana di Kabupaten Bima. Dan bagi masyarakat, dapat mengetahui daerah-daerah yang berpotensi terkena bencana kekeringan sekaligus dapat menjadi peringatan dini terutama bagi masyarakat yang bertempat tinggal di kawasan paling risiko kekeringan. Perbedaan penelitian ini dengan penelitian-penelitian sebelumnya tidak hanya dari lokasi penelitian, tetapi juga tujuan penelitian, variabel penelitian, metode penelitian, dan cakupan bahasan.

\section{DATA DAN METODE}

\subsection{Data}

Kebutuhan data dalam penelitian ini meliputi 2 (dua) jenis data, yaitu data spasial dan data nonspasial. Data spasial terdiri atas data raster yang berupa data model ketinggian (Digital Elevation Model) dan data vektor yang berupa peta-peta yang terkait dengan variabel-variabel kerawanan kekeringan. Sedangkan data non-spasial terdiri dari data tabular yang berupa data demografi dan data pendukung gambaran umum wilayah studi.

Tabel 1. Kebutuhan Data (Penyusun, 2018)

\begin{tabular}{|c|c|c|c|c|}
\hline No & Data & Format Data & Jenis Data & Sumber \\
\hline 1. & Peta administrasi wilayah & Vektor & Sekunder & Bappeda \\
\hline 2. & Data dan peta curah hujan & Vektor & Sekunder & BMKG \\
\hline 3. & Digital Elevation Model (DEM-SRTM) & Raster & Sekunder & http://www.cgiar-csi.org \\
\hline 4. & Peta jenis tanah & Vektor & Sekunder & Bappeda \\
\hline 5. & Peta geologi & Vektor & Sekunder & Bappeda \\
\hline 6. & Peta jaringan sungai & Vektor & Sekunder & Bappeda \\
\hline 7. & Peta tutupan lahan & Vektor & Sekunder & Bappeda \\
\hline 8. & Data jumlah penduduk & Tabular & Sekunder & BPS \\
\hline 9. & Data jumlah penduduk menurut kelompok umur & Tabular & Sekunder & BPS \\
\hline 10. & Data jumlah penduduk di sektor pertanian & Tabular & Sekunder & BPS \\
\hline 11. & Data produktivitas lahan & Tabular & Sekunder & BPS \\
\hline 12. & Data jumlah ternak & Tabular & Sekunder & BPS \\
\hline 13. & Data luas hutan & Tabular & Sekunder & BPS \\
\hline
\end{tabular}




\subsection{Metode}

Penelitian ini menggunakan pendekatan keruangan/spasial dengan metode kuantitatif yang menggunakan indikator statistik untuk mengukur dan membandingkan berbagai variabel. Pendekatan keruangan bertujuan untuk melihat bencana kekeringan dari sudut pandang keruangan/spasial. Pengumpulan data dilakukan dengan survei instansional dan literatur. Data yang digunakan adalah data sekunder. Teknik analisis data yang digunakan adalah analisis skoring, pembobotan, dan overlay peta.

Skoring atau pemberian skor adalah suatu proses pengubahan jawaban menjadi angka-angka yang merupakan nilai kuantitatif (Djaali \& Muljono, 2007). Skoring ini didasarkan pada teori-teori tentang faktor kerawanan kekeringan, referensi penelitian-penelitian sebelumnya, dan pengalaman empiris lapangan tentang seberapa besar pengaruh kelas tersebut terhadap kekeringan. Semakin tinggi pengaruhnya terhadap kekeringan maka skor yang diberikan akan semakin tinggi. Pemberian skor terhadap parameterparameter ini dilakukan secara linier terhadap kelas-kelas dalam suatu parameter kekeringan dengan skor 1 - 5. Skor 1 (satu) diberikan untuk kelas yang tidak terlalu berpengaruh atau mempunyai pengaruh yang kecil terhadap kekeringan, sedangkan skor 5 (lima) diberikan untuk kelas yang mempunyai pengaruh yang besar terhadap kekeringan.

Metode pembobotan yang digunakan dalam penelitian ini adalah metode ranking. Metode ranking adalah metode yang paling sederhana untuk pemberian nilai bobot (Banda, 2002). Setiap parameter akan disusun berdasarkan ranking. Penentuan ranking bersifat subjektif, misalnya parameter paling penting diberi nilai 1, parameter penting diberi nilai 2 dan parameter kurang penting diberi nilai 3, atau dapat juga dengan pendekatan kebalikan misalnya parameter kurang penting diberi nilai 1, penting diberi nilai 2 dan paling penting bernilai 3. Pembobotan dengan cara ini dihitung menurut rumus:

$$
W j=\frac{\left(\mathrm{n}-r_{j}+1\right)}{\sum\left(\mathrm{n}-r_{p}+1\right)}
$$

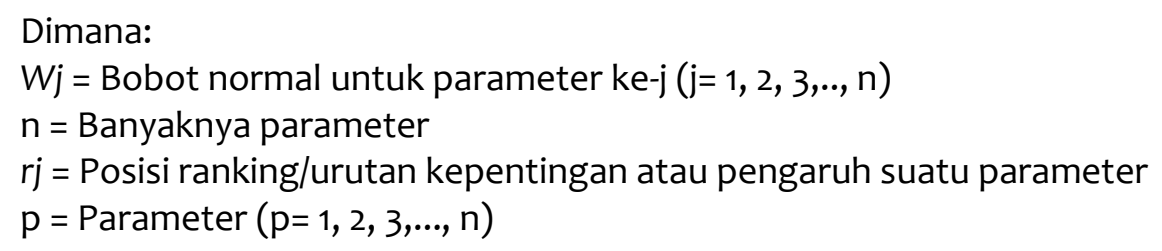

\section{HASIL DAN PEMBAHASAN}

\subsection{Konsep Model Pemetaan Risiko Kekeringan}

Risiko kekeringan adalah potensi kerugian yang ditimbulkan akibat kekeringan yang terjadi di suatu wilayah yang berupa berkurangnya pasokan air untuk menunjang kehidupan sehari-hari, gagal panen, dan rusaknya lingkungan. Analisis risiko pada umumnya dihasilkan dari analisis bahaya atau kerawanan (Hazard) dan kerentanan (Vulnerabiliity). Semakin tinggi kerawanan di suatu wilayah maka semakin tinggi pula risiko daerah tersebut terkena bencana. Hal ini juga berlaku untuk kerentanan, dimana semakin tinggi tingkat kerentanan maka semakin tinggi pula tingkat risikonya. Namun pada perkembangannya, hingga saat ini, telah banyak berkembang model risiko bencana seiring dengan berkembangnya penelitian terkait risiko bencana. Misalnya seperti Probabilitas, Kerugian, Keterpaparan, dan Kapasitas, merupakan pengembangan atau turunan dari Hazard dan Vulnerability. Adapun model risiko yang akan digunakan sebagai dasar penelitian adalah:

Dimana:

$$
\mathbf{R}=\mathbf{H} * \mathbf{V}
$$

$\mathrm{R}=$ Risk (Risiko),

$\mathrm{H}=$ Hazard (Bahaya/Kerawanan),

$\mathrm{V}=$ Vulnerability (Kerentanan). 
Adapun alasan mengapa model risiko ini digunakan sebagai dasar metode dan analisis dalam penelitian ini, antara lain sebagai berikut:

1. Komponen Bahaya/Kerawanan (Hazard) dan Komponen Kerentanan (Vulnerability) merupakan dua komponen dasar dalam setiap kajian risiko bencana. Hal ini dikarenakan pada dasarnya bencana alam umumnya dianggap sebagai kejadian yang tidak disengaja antara bahaya alam (seperti banjir, tsunami, gempabumi, kekeringan, dan lain sebagainya) dan kondisi kerentanan. Ada risiko tinggi bencana ketika satu atau lebih bahaya alam terjadi dalam situasi yang rentan.

2. Untuk komponen lainnya seperti Probabilitas, Kerugian, Keterpaparan, dan Kapasitas, merupakan pengembangan dari Hazard dan Vulnerability. Seperti misalnya Probabilitas yang merupakan kemungkinan-kemungkinan berdasarkan peristiwa yang telah terjadi dan akan terjadi, yang mana merupakan pengembangan dari Hazard. Contoh lainnya adalah Keterpaparan yang merupakan turunan atau pengembangan dari Vulnerability, dimana keterpaparan ini merupakan aspek sosial dari Vulnerability. Begitupun untuk komponen Kapasitas, juga merupakan pengembangan dari Vulnerability, dimana Kapasitas merupakan upaya kesiapsiagaan manusia dalam mengurangi risiko bencana.

3. Pada intinya, risiko bencana adalah ketika bahaya alam (natural hazard) terjadi pada kondisi yang rentan (vulnerable). Besarnya bahaya, fenomena, kemungkinan terjadinya dan tingkat dampaknya dapat bervariasi. Kerentanan tidak statis tetapi harus dianggap sebagai proses yang dinamis, mengintegrasikan perubahan dan perkembangan yang mengubah dan mempengaruhi kemungkinan kehilangan dan kerusakan.

\subsection{Model Pemetaan Kerawanan Kekeringan (Hazard)}

Variabel yang digunakan untuk menyusun model pemetaan kerawanan kekeringan adalah curah hujan rata-rata tahunan, kemiringan lereng, jenis tanah, geologi/jenis batuan penyusun, jarak dari sumber air, dan tutupan lahan. Variabel-variabel ini dianalisis menggunakan pendekatan skoring lalu diberi bobot pada masing-masing variabel.

Konsep pembobotan variabel komponen kerawanan kekeringan didasarkan pada seberapa besar pengaruh variabel tersebut memicu terjadinya kekeringan dengan uraian sebagai berikut: Proses terjadinya kekeringan diawali dengan berkurangnya intensitas curah hujan yang menjadi indikator awal terjadinya kekeringan. Air hujan yang jatuh akan mengalir dari tempat yang tinggi ke tempat yang rendah, maka kemiringan lereng suatu wilayah cukup berpengaruh. Selanjutnya, ketersediaan dan bertahannya air di dalam tanah dipengaruhi oleh jenis tanah dan jenis batuan penyusun wilayah tersebut. Dinilai dari kemampuannya meloloskan air. Keempat kondisi tersebut secara tidak langsung berkaitan juga dengan sumber air di permukaan tanah. Dalam hal kekeringan, jarak dari sumber air juga berpengaruh pada rawan kekeringan. Selanjutnya, tutupan lahan tergantung pada jenis tanah dan jenis batuan penyusun atau struktur geologi.

Berdasarkan ulasan tersebut, maka variabel parameter diurut berdasarkan tingkat pengaruhnya terhadap kerawanan kekeringan. Urutan pengaruh pertama diberi bobot paling tinggi, begitu seterusnya, sehingga diperoleh bobot yang dinormalkan dengan menggunakan metode ranking (pers. 1).

Setelah diberi skor dan bobot, semua variabel kerawanan kekeringan ditumpangtindih (overlay). Pembuatan peta kerawanan kekeringan dilakukan dengan cara menggabungkan atau menjumlahkan nilai skor keseluruhan dari hasil tumpang tindih peta tematik penyebab kekeringan yang disusun. Kemudian direklasifikasi ke dalam 5 kelas rawan tanpa mengurangi substansi masing-masing kelas tersebut berdasarkan Natural Breaks. 


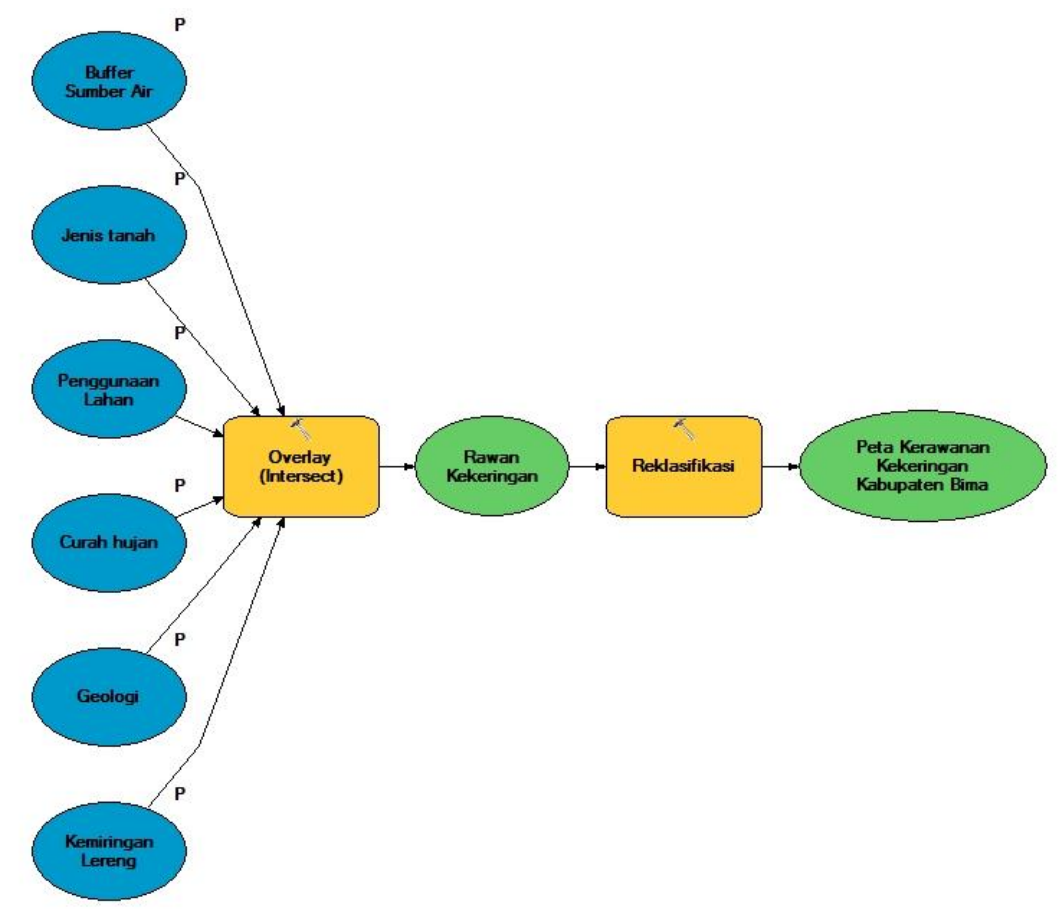

Sumber: Hasil Analisis, 2018

Gambar 1. Model pemetaan kerawanan kekeringan dengan ArcGIS ModelBuilder

Berdasarkan analisis yang telah dilakukan, diperoleh 5 (lima) kriteria kelas kerawanan bencana kekeringan di Kabupaten Bima, yaitu Tidak Rawan, Cukup Rawan, Sedang, Rawan, dan Sangat Rawan. Adapun rinciannya dapat dilihat pada tabel berikut ini.

Tabel 2. Luasan daerah rawan kekeringan Kabupaten Bima

\begin{tabular}{llr}
\hline No & \multicolumn{1}{c}{ Kategori } & \\
\hline 1 & Tidak Rawan & Luas (Ha) \\
2 & Cukup Rawan & $77.866,94$ \\
3 & Sedang & $218.300,38$ \\
4 & Rawan & $105.819,29$ \\
5 & Sangat Rawan $\quad$ Jumlah & $3.031,00$ \\
& & $\mathbf{4 2 0 . 3 5 4 , 3 1}$ \\
\hline
\end{tabular}

Sumber: Hasil Analisis, 2018

Berdasarkan tabel di atas, sebagian besar wilayah Kabupaten Bima merupakan area kekeringan dengan klasifikasi sedang dan rawan, yaitu masing-masing seluas $\pm 218.300,38 \mathrm{Ha}$ dan $\pm 105.819,29 \mathrm{Ha}$.

Secara umum daerah rawan kekeringan tersebar pada hampir seluruh wilayah Kabupaten Bima. Jika dirinci berdasarkan variabel kerawanan kekeringan, dapat disimpulkan bahwa tingkat atau kelas yang paling mendominasi tiap variabel adalah cukup beragam. Pada variabel curah hujan rata-rata tahunan, kelas yang mendominasi adalah kelas Sedang. Pada variabel kemiringan lereng, kelas yang mendominasi adalah kelas Agak tinggi. Pada variabel jenis tanah, kelas yang mendominasi adalah kelas Agak tinggi. Pada variabel geologi/jenis batuan penyusun, kelas yang mendominasi adalah kelas Rendah. Pada variabel jarak dari sumber air, kelas yang mendominasi adalah kelas Tinggi. Dan pada variabel tutupan lahan, kelas yang mendominasi adalah kelas Agak rendah. Sehingga setelah dilakukan analisis menghasilkan kelas kerawanan kekeringan yang paling mendominasi adalah kelas Sedang. 
Faizah, Buchori/ Jurnal Pembangunan Wilayah dan Kota, Vol.15, No.2, 2019, 138-150 Doi: https://doi.org/10.14710/pwk.v15i2.19621

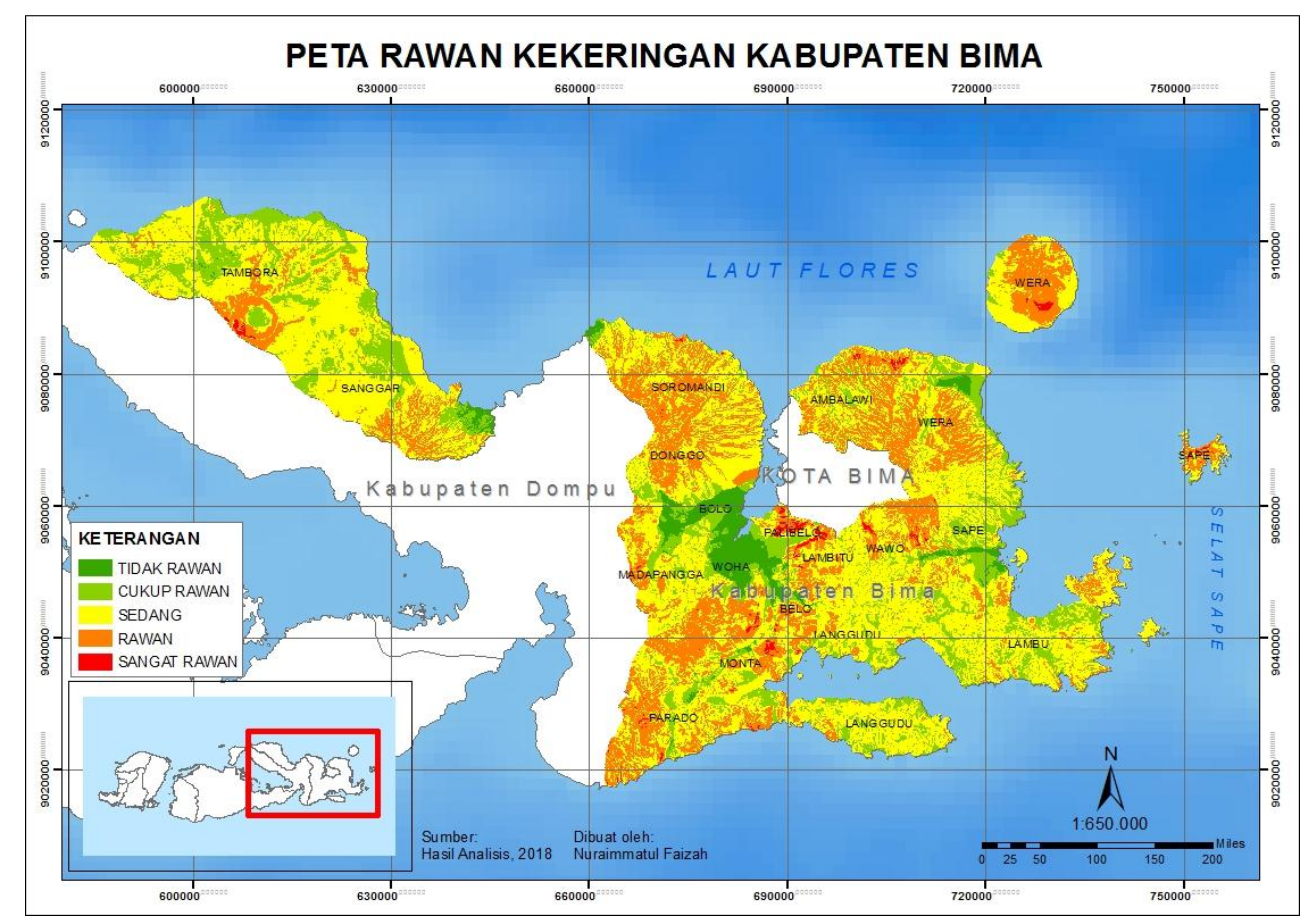

Sumber: Hasil Analisis, 2018

Gambar 2. Peta rawan kekeringan Kabupaten Bima

3.3 Model Pemetaan Kerentanan Terhadap Kekeringan (Vulnerability)

Analisis kerentanan ini dilakukan untuk mengetahui tingkat ketidakmampuan suatu wilayah untuk menghadapi bencana kekeringan. Kerentanan yang dimaksud dalam penelitian ini ditinjau dari aspek sosial, ekonomi, dan lingkungan. Total kerentanan merupakan jumlah dari setiap variabel kerentanan berdasarkan faktor skoring, pembobotan, dan overlay. Output yang dihasilkan yaitu peta kerentanan terhadap kekeringan.

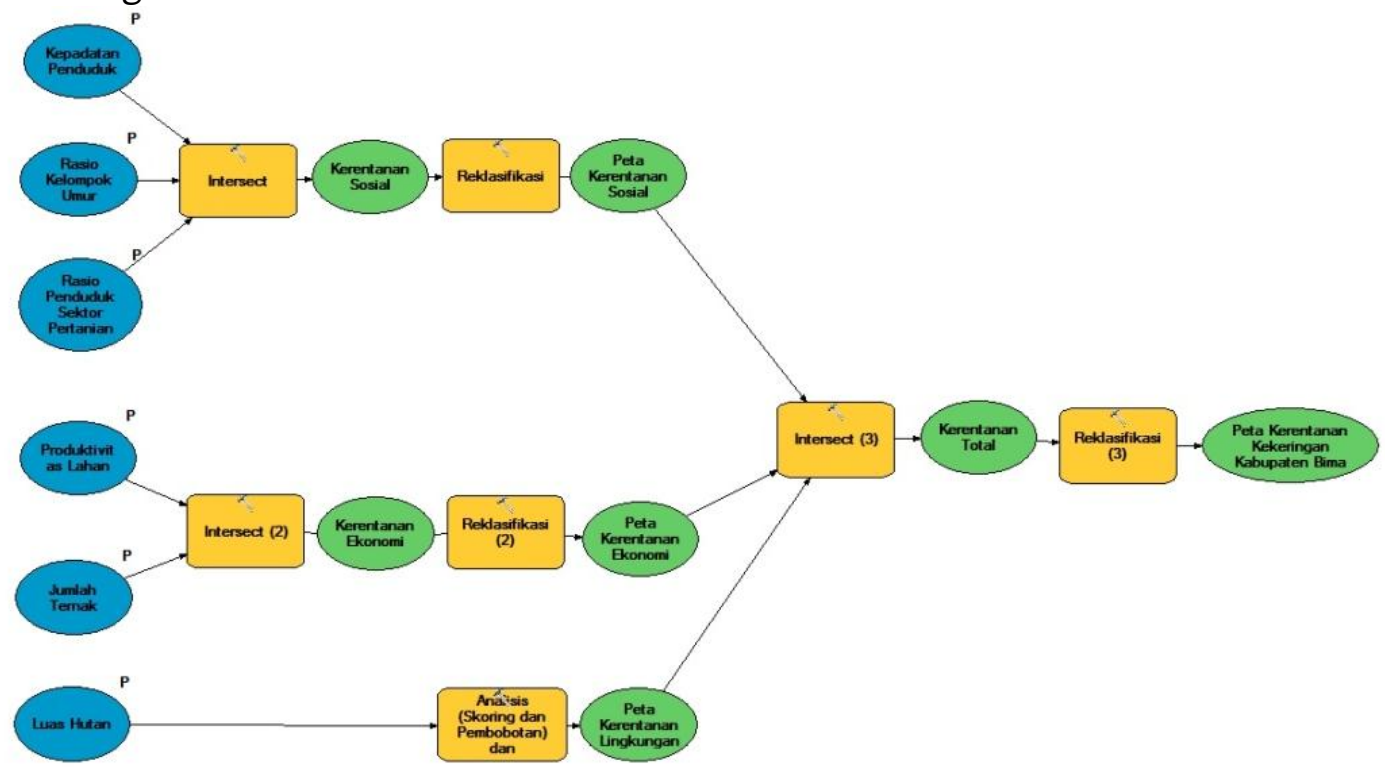

Sumber: Hasil Analisis, 2018

Gambar 3. Model pemetaan kerentanan terhadap kekeringan dengan ArcGIS ModelBuilder 


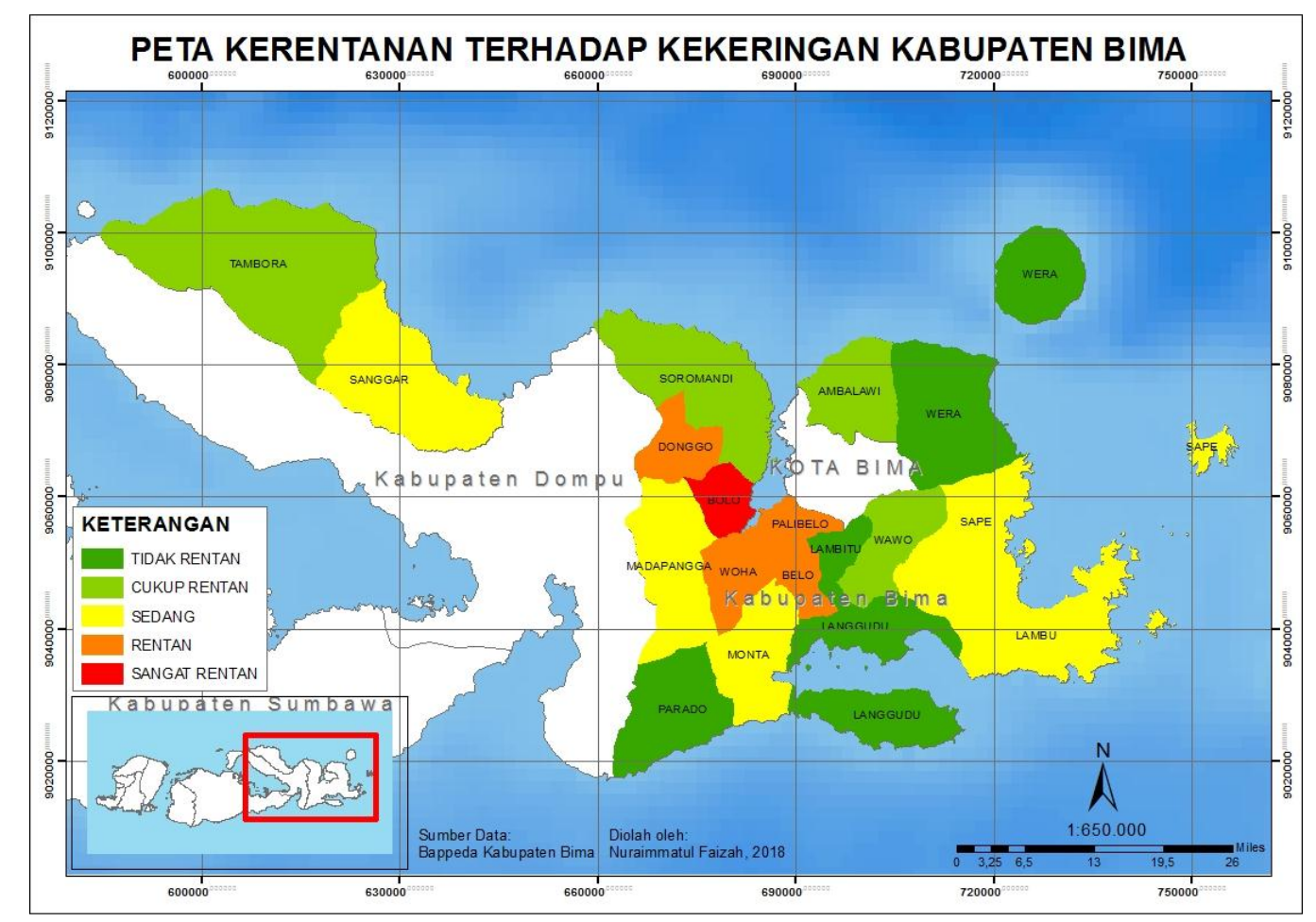

Sumber: Hasil Analisis, 2018

Gambar 4. Peta kerentanan kekeringan Kabupaten Bima

Berdasarkan analisis tersebut, tingkat kerentanan terhadap kekeringan di Kabupaten Bima terbagi dalam 5 kelas, yaitu Tidak rentan, Cukup rentan, Sedang, Rentan, dan Sangat rentan, dengan didominasi oleh kelas Sedang yang meliputi 5 kecamatan. Sedangkan kelas Tidak rentan meliputi 3 kecamatan, kelas Cukup rentan meliputi 4 kecamatan, kelas Rentan meliputi 4 kecamatan, yaitu Kecamatan Donggo, Woha, Palibelo, dan Belo, dan kelas Sangat Rentan hanya meliputi 1 kecamatan, yaitu Kecamatan Bolo.

\subsection{Model Pemetaan Risiko Kekeringan (Risk)}

Model pemetaan risiko kekeringan merupakan overlay antara kerawanan kekeringan (Hazard) dengan kerentanan terhadap kekeringan (Vulnerability). Rumus fungsi pemetaan risiko yang digunakan dalam penelitian ini adalah sebagai berikut:

\section{Risiko $=($ Bahaya $/$ Kerawanan $) *($ Kerentanan $)$}

Peta risiko kekeringan yang dihasilkan dapat menggambarkan wilayah potensial terjadinya bencana kekeringan di wilayah Kabupaten Bima. Berdasarkan analisis yang telah dilakukan, diperoleh beberapa kriteria kelas risiko kekeringan di Kabupaten Bima. Luas wilayah dengan kelas dari yang tertinggi ke yang terendah yaitu Sedang $\pm 223.232,40$ ha, Agak rendah $\pm 136.414,29$ ha, Agak tinggi $\pm 47.971,49$ ha, Rendah $\pm 10.962,28$ ha dan Tinggi $\pm 1.776,53$ ha. Dengan demikian secara umum sebagian besar wilayah Kabupaten Bima mempunyai risiko kekeringan dengan kategori sedang. 


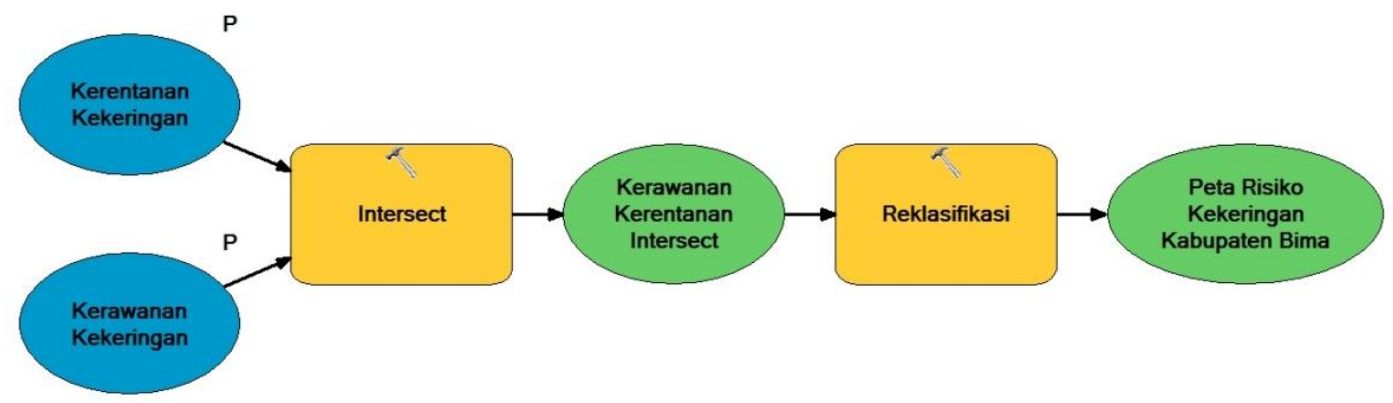

Sumber: Hasil Analisis, 2018

Gambar 5. Model pemetaan risiko kekeringan dengan ArcGIS ModelBuilder

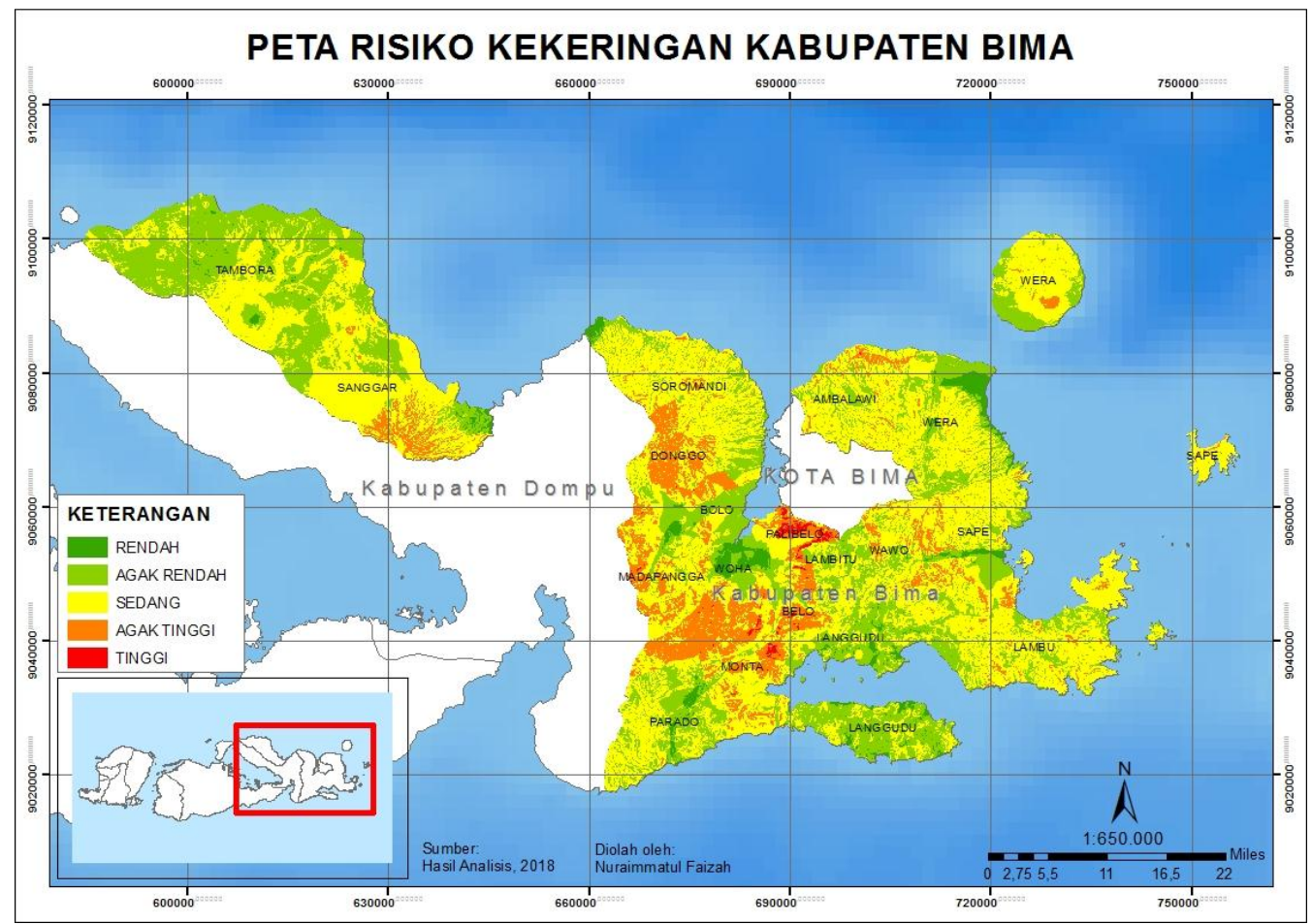

Sumber: Hasil Analisis, 2018

Gambar 6. Peta risiko kekeringan Kabupaten Bima

Berdasarkan sebaran spasial risiko kekeringan, tingkat risiko kekeringan dengan kategori Agak tinggi dan Tinggi tersebar bagian tengah Kabupaten Bima yaitu tersebar di Kecamatan Ambalawi, Belo, Bolo, Donggo, Madapangga, Monta, Palibelo, Sape, dan Woha. Sedangkan tingkat risiko kekeringan di wilayah lainnya didominasi oleh kategori Agak rendah dan Sedang.

\subsection{Validasi}

Validasi merupakan tahap akhir dari suatu pemodelan spasial. Validasi dilakukan untuk menguji apakah hasil pemodelan dapat secara tepat memprediksi suatu kasus. Dalam penelitian ini, tujuan validasi model adalah untuk mengukur keakuratan atau ketepatan model dalam menduga risiko kekeringan dengan kondisi sebenarnya di lapangan. Hal ini dilakukan apakah pemodelan yang telah dibuat dapat 
memprediksi tingkat risiko kekeringan secara tepat. Validasi dilakukan dengan observasi lapangan atau groundcheck. Observasi lapangan tidak dilakukan pada seluruh Kabupaten Bima, namun hanya khusus pada daerah yang memiliki tingkat risiko kekeringan yang agak tinggi hingga tinggi dan dibagi dalam 3 zona.

Zonasi wilayah dilakukan untuk memudahkan validasi model dan observasi lapangan. Selanjutnya, observasi lapangan dilakukan dengan menggunakan alat bantu GPS (Global Positioning System) serta alat dokumentasi berupa kamera. Penentuan titik lokasi sampel dilakukan hanya pada daerah yang memiliki tingkat risiko kekeringan yang agak tinggi hingga tinggi. Spatial sampling dilakukan dengan membuat grid dengan penentuan luasan secara asumsi dan plotting peta. Dalam satu grid dianggap masih memiliki karakteristik fisik yang sama dengan luas $50 \mathrm{~km}^{2}$, sehingga dalam satu Kabupaten Bima dengan luas $4.389,40 \mathrm{~km}^{2}$ akan diperoleh 61 grid dan titik. Berikut ini adalah peta validasi model yang dilakukan.

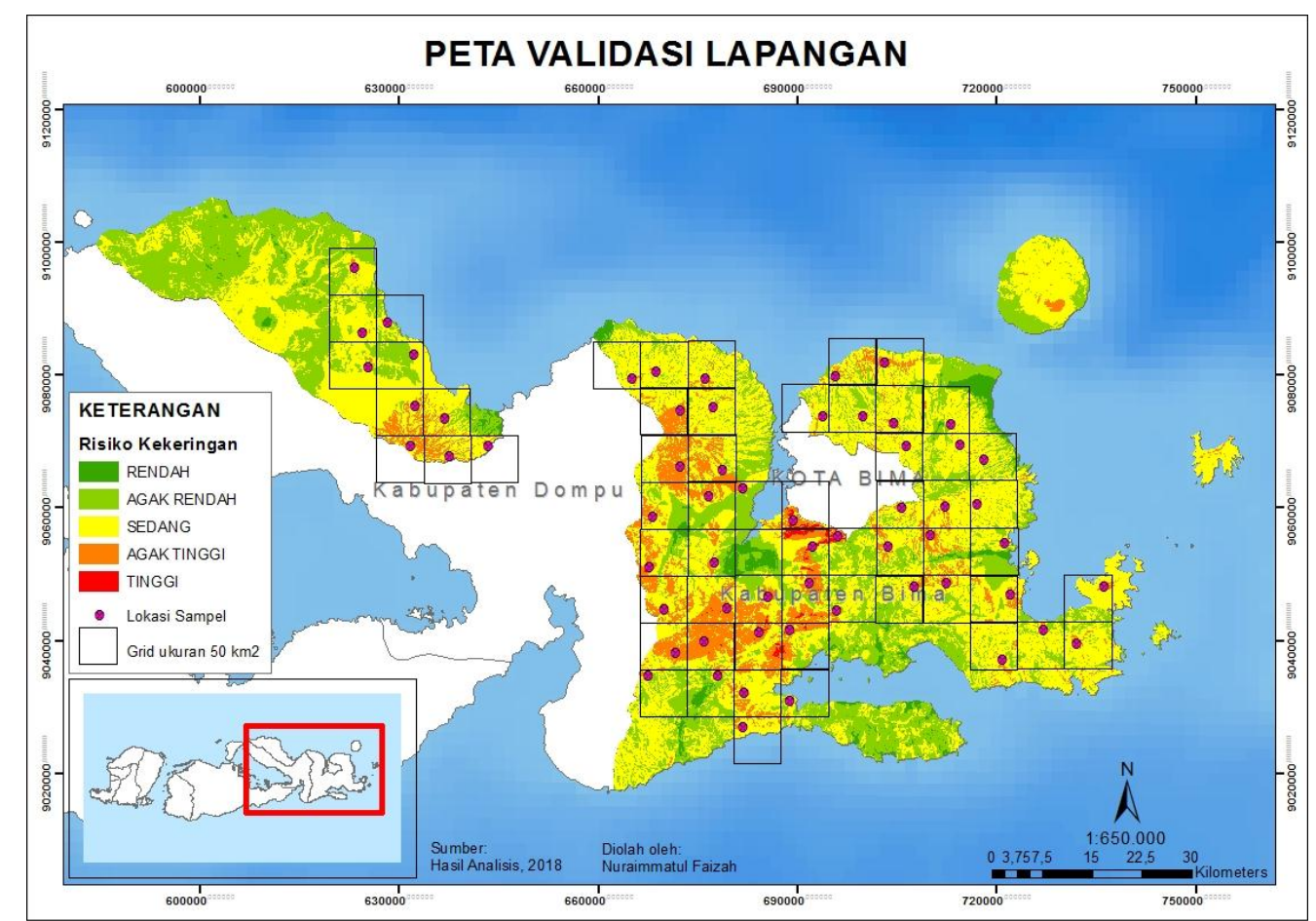

Sumber: Hasil Analisis, 2018

\section{Gambar 7. Peta validasi lapangan}

Dari total 61 titik validasi yang diambil dari hasil observasi lapangan, terdapat 51 titik yang sesuai dan 10 titik yang tidak sesuai dengan model yang dibangun. Dengan adanya ketidakvalidan pada 10 titik dari total 61 titik sampel, maka kevalidan model pemetaan risiko kekeringan yang telah dilakukan pada penelitian ini adalah sebesar $83,61 \%$. Dengan demikian, model pemetaan telah mampu menggambarkan persebaran daerah risiko kekeringan di Kabupaten Bima.

Adanya beberapa titik yang tidak valid antara model dengan kondisi nyata di lapangan dikarenakan oleh model risiko yang digunakan, data yang digunakan terutama data time-series tahunan curah hujan. Karena validasi lapangan yang merupakan observasi langsung pada kondisi terbaru tidak bisa merepresentasikan curah hujan selama setahun.

Hal ini juga berlaku dalam unit analisis tiap komponen, yang mana komponen kerawanan kekeringan unit analisisnya adalah kriteria dalam setiap variabel penyusun analisis kerawanan, sedangkan pada komponen kerentanan terhadap kekeringan unit analisisnya adalah batasan kecamatan. Jadi, hal ini sedikitbanyak juga turut mempengaruhi peta risiko kekeringan yang dihasilkan. Selain itu, validasi yang dilakukan 
Faizah, Buchori/ Jurnal Pembangunan Wilayah dan Kota, Vol.15, No.2, 2019, 138-150

Doi: https://doi.org/10.14710/pwk.v15i2.19621

juga cukup mempengaruhi, dimana validasi dilakukan hanya pada 2 kelas risiko saja, bukan pada seluruh kelas (5 kelas risiko).

\section{KESIMPULAN}

Model risiko bencana yang digunakan sebagai dasar penelitian ini adalah interseksi antara bahaya/kerawanan dengan kerentanan. Adapun alasannya karena model ini merupakan model yang paling dasar dalam kajian risiko bencana. Hal ini didasarkan pada risiko bencana terjadi ketika satu atau lebih bahaya alam terjadi dalam situasi yang rentan. Hasil model pemetaan kerawanan kekeringan, diperoleh 5 (lima) kriteria kelas kerawanan bencana kekeringan di Kabupaten Bima, yaitu Tidak Rawan, Cukup Rawan, Sedang, Rawan, dan Sangat Rawan. Sebagian besar wilayah Kabupaten Bima merupakan area kekeringan dengan klasifikasi sedang dan rawan, yaitu masing-masing seluas $\pm 218.300,38 \mathrm{Ha}$ dan $\pm 105.819,29 \mathrm{Ha}$, dan menyebar hampir di seluruh wilayah Kabupaten Bima. Untuk model pemetaan kerentanan terhadap kekeringan, tingkat kerentanan terhadap kekeringan di Kabupaten Bima terbagi dalam 5 kelas, yaitu Tidak rentan, Cukup rentan, Sedang, Rentan, dan Sangat rentan, dengan didominasi oleh kelas Sedang yang meliputi 5 kecamatan. Sedangkan kelas Tidak rentan meliputi 3 kecamatan, kelas Cukup rentan meliputi 4 kecamatan, kelas Rentan meliputi 4 kecamatan, yaitu Kecamatan Donggo, Woha, Palibelo, dan Belo, dan kelas Sangat Rentan hanya meliputi 1 kecamatan, yaitu Kecamatan Bolo. Sedangkan hasil model pemetaan risiko kekeringan, risiko kekeringan di Kabupaten Bima diklasifikasikan menjadi 5 kelas, yaitu Tinggi, Agak tinggi, Sedang, Agak rendah, dan Rendah. Luas wilayah dengan kelas dari yang tertinggi ke yang terendah yaitu Sedang $\pm 223.232,40$ ha, Agak rendah $\pm 136.414,29$ ha, Agak tinggi $\pm 47.971,49$ ha, Rendah $\pm 10.962,28$ ha dan Tinggi $\pm 1.776,53$ ha.

Validasi lapangan dilakukan dengan observasi lapangan pada wilayah yang berisiko Agak tinggi dan Tinggi berdasarkan model. Observasi lapangan dilakukan melalui Spatial Sampling dengan asumsi. Asumsi digunakan pada penentuan jumlah titik sampel. Untuk mempermudah penentuan titik sampel, wilayah Kabupaten Bima dengan luas $4.389,40 \mathrm{~km}^{2}$ dibagi ke dalam beberapa grid. Satu grid memiliki luas $\pm 50 \mathrm{~km}^{2}$. Satu titik mewakili $\pm 50 \mathrm{~km}^{2}$, sehingga diperoleh jumlah sampel sebanyak 61 titik. Setelah dilakukan validasi, didapatkan 51 titik valid dan 10 titik tidak valid (error). Sehingga tingkat kevalidan model yang dibangun adalah $83,61 \%$. Adanya beberapa titik yang tidak valid antara model dengan kondisi nyata di lapangan dikarenakan oleh model risiko yang digunakan, data yang digunakan terutama data time-series tahunan curah hujan, unit analisis yang digunakan dalam tiap komponen, yang mana komponen kerawanan kekeringan unit analisisnya adalah kriteria dalam setiap variabel penyusun analisis kerawanan, sedangkan pada komponen kerentanan terhadap kekeringan unit analisisnya adalah batasan kecamatan. Jadi, hal ini sedikit-banyak juga turut mempengaruhi peta risiko kekeringan yang dihasilkan. Selain itu, validasi yang dilakukan juga cukup mempengaruhi, dimana validasi dilakukan hanya pada 2 kelas risiko saja (kelas risiko Agak tinggi dan Tinggi), bukan pada seluruh kelas ( 5 kelas risiko). Pada dasarnya setiap model pemetaan bersifat dinamis, termasuk model yang dikembangkan dalam penelitian ini. Oleh karena itu, untuk dapat diterapkan pada lokasi lain perlu adanya penyesuaian model antara lokasi satu dengan lokasi lainnya. Untuk penggunaan data, diperlukan data time-series curah hujan bulanan atau harian agar lebih akurat. Untuk unit analisis, terutama unit analisis dalam parameter kerentanan wilayah, diperlukan data dalam lingkup yang lebih kecil lagi seperti batasan desa atau RT maupun RW. Dan untuk melakukan validasi yang lebih baik dilakukan dengan memperkecil satuan grid yang mewakili satu titik serta dilakukan pada semua kriteria risiko kekeringan (Rendah, Agak rendah, Sedang, Agak tinggi, dan Tinggi) berdasarkan model.

\section{PERNYATAAN RESMI}

Ucapan terima kasih Penulis tujukan pada semua pihak yang telah berperan dalam penelitian ini terutama Pemerintah Kabupaten Bima yang telah berkenan memberikan data dan informasi serta Prof. Dr.rer.nat. Imam Buchori, ST., yang telah memberikan masukan dan arahan dalam penelitian ini. 
Faizah, Buchori/ Jurnal Pembangunan Wilayah dan Kota, Vol.15, No.2, 2019, 138-150

Doi: https://doi.org/10.14710/pwk.v15i2.19621

\section{REFERENSI}

Badan Nasional Penanggulangan Bencana. (2010). Peta Indeks Risiko Bencana Kekeringan/Drought Disaster Risk Index Map.

Bakornas PB. (2007). Pengenalan Karakteristik Bencana dan Upaya Mitigasinya di Indonesia Cetakan Edisi II.

Banda, M. (2002). Pembobotan Parameter dan Penentuan Keputusan. Modul Praktikum Sistem Informasi Geografis, 38-49.

Diaz, V., Corzo, G., Solomatine, D., \& Van, H. A. J. (2016). Spatio-temporal analysis of hydrological drought at catchment scale using a spatially-distributed hydrological model. Procedia Engineering, 154, 738-744. http://doi.org/10.1016/j.proeng.2016.07.577

Djaali \& Pudji Muljono. (2007). Pengukuran Dalam Bidang Pendidikan. Jakarta: Grasindo.

Fontaine, M. M., Steinemann, A. C., \& Asce, M. (2009). Assessing Vulnerability to Natural Hazards : Impact-Based Method and Application to Drought in Washington State, 10(1), 11-18. http://doi.org/10.1061/(ASCE)15276988(2009)10:1(11)

Hayes, M., Svoboda, M., Wall, N., \& Widhalm, M. (2011). The Lincoln Declaration on Drought Indices: Universal Meteorological Drought Index Recommended. Bulletin of the American Meteorological Society, 4(92), 485-488. http://doi.org/10.1175/2010BAMS3103.1

Jia, J., Han, L., Liu, Y., He, N., Zhang, Q., \& Wan, X. (2016). Acta Ecologica Sinica Drought risk analysis of maize under climate change based on natural disaster system theory in Southwest China. CHNAES, 36(5), 340-349. http://doi.org/10.1016/j.chnaes.2016.06.001

Kim, H., Park, J., Yoo, J., \& Kim, T. (2015). ScienceDirect Assessment of drought hazard, vulnerability , and risk : A case study for administrative districts in South Korea. Journal of Hydro-Environment Research, 9(1), $28-35$. http://doi.org/10.1016/j.jher.2013.07.003

Knutson, C., Hayes, M., \& Phillips, T. (1998). How to Reduce Drought Risk: A Guide Prepared by The Preparedness and Mitigation Working Group of the Western Drought Coordination Council. National Drought Mitigation Center, Lincoln, Nebraska.

Lin, M. L., Chu, C. M., \& Tsai, B. W. (2011). Drought Risk Assessment in Western Inner-Mongolia, 5(1), $139-148$.

Loon, A. F. Van. (2015). Hydrological drought explained, 2(August), 359-392. http://doi.org/10.1002/wat2.1085

Maskrey, A. (1989). Disaster Mitigation: A Community Based Approach. Oxford: Oxfam.

Mathbout, S., Lopez-bustins, J. A., Martin-vide, J., Bech, J., \& Rodrigo, F. S. (2018). Spatial and temporal analysis of drought variability at several time scales in Syria during 1961 - 2012. Atmospheric Research, 200(May 2017), 153168. http://doi.org/10.1016/j.atmosres.2017.09.016

Mohammed, R., \& Scholz, M. (2017). Impact of Evapotranspiration Formulations at Various Elevations on the Reconnaissance Drought Index. Water Resources Management, 531-548. http://doi.org/10.1007/s11269-016-1546-9

Naumann, G., Barbosa, P., \& Carra, H. (2016). Mapping global patterns of drought risk : An empirical framework based on sub-national estimates of hazard, exposure and, 39, 108-124. http://doi.org/10.1016/j.gloenvcha.2016.04.012

Okada, N., Tatano, H., Hagihara, Y., Suzuki, Y., Nagae, T., Shimizu, H., \& Researcher, C. O. E. (2004). Integrated Research on Methodological Development of Urban Diagnosis for Disaster Risk and its Applications Vulnerability Exposure Hazard, (47).

Peraturan Kepala Badan Nasional Penanggulangan Bencana Nomor 4. (2008). Pedoman Penyusunan Rencana Penanggulangan Bencana.

Prabowo, K. (2016). Analisis Risiko Bencana Kekeringan di Kabupaten Klaten. Universitas Muhammadiyah Surakarta.

Reed, S. B. (1995). Pengantar Tentang Bahaya (Program Pelatihan Manajemen Bencana UNDP). New York: United Nations Development Programme.

Shahid, S., \& Behrawan, ÆE. H. (2008). Drought risk assessment in the western part of Bangladesh, 391-413. http://doi.org/10.1007/s11069-007-9191-5

Valverde-arias, O., Garrido, A., Valencia, L., \& Marı, A. (2018). Using geographical information system to generate a drought risk map for rice cultivation: Case study in Babahoyo canton (Ecuador). Biosystems Engineering, 168, 2641. http://doi.org/10.1016/j.biosystemseng.2017.08.007

Verdon-Kidd, D. C., \& Kiem, A. S. (2010). Quantifying Drought Risk in a Nonstationary Climate. Journal of Hydrometeorology, 11(2000), 1019-1031. http://doi.org/10.1175/2010JHM1215.1

Wilhite, D. A., \& Glantz, M. H. (1985). Understanding the Drought Phenomenon: The Role of Definitions. Water International 10, 3(1985), 111-120. 
Faizah, Buchori/ Jurnal Pembangunan Wilayah dan Kota, Vol.15, No.2, 2019, 138-150 Doi: https://doi.org/10.14710/pwk.v15i2.19621

Wisner, B., Blaikie, P., Cannon, T., \& Davis, I. (2003). At Risk: Natural Hazards, People's Vulnerability and Disasters (Second). Routledge, London.

Wu, H., \& Wilhite, D. A. (2004). An Operational Agricultural Drought Risk Assessment Model for Nebraska, USA. Natural Hazards 33, 1-21. National Drought Mitigation Center, Lincoln, Nebraska.

Yan, J. (2010). Disaster Risk Assessment: Disaster Risk Mapping. Training Workshop on Drought Risk Assessment for the Agricultural Sector - Ljubijana, Slovenia. Sept 20-24, 2010. 